\title{
Chapter 8: The role of stakeholder networks in shaping the development of social enterprise ecosystems
}

\author{
Authors: Richard Hazenberg, Meanu Bajwa-Patel, Toa Giroletti
}

\begin{abstract}
This chapter will explore the role of stakeholder and institutional networks in shaping the development of social enterprise ecosystems across Europe. A Weberian view of power is adopted in order to show that dominant stakeholders can distort reality, obscure truth, and create paradigmatic narratives while pursuing their own interests. This chapter will also draw upon biological evolutionary theory, social network theory, and network pluralism to identify a typology of social enterprise ecosystems. This typology was developed based upon qualitative data (semi-structured interviews and focus groups) collected across 11 European countries from 258 key stakeholders, while also exploring the historical, political, social, legal, and economic conditions in each country. The data was used to create stakeholder network maps for each country, which were then analyzed to identify trends and linkages. The results identify the emergence of four social enterprise ecosystem types (Statist-macro, Statist-micro, Private-macro, and Private-micro) that help explain the differences found in the social enterprise ecosystems of all eleven countries. The emergence of an "ideal-type" ecosystem is posited in relation to these four types, which can be used by stakeholders across Europe to understand how best to support their local social economies.
\end{abstract}

\section{Introduction}

The field of social entrepreneurship and the study of social enterprises has grown rapidly over the last decade, with scholarly interest in the field emerging around the world. Indeed, explorations of social entrepreneurship have identified several different types of social enterprises (see, for example, Defourny \& Nyssens, 2008, 2010; Doherty et al., 2009; Galera \& Borzaga, 2009; Kerlin, 2006, 2010, 2013), while prior research by Mendell (2010) found that their emergence is often rooted in the various institutional contexts of the countries and/or regions in which they operate. This focus on geographic differences and institutional factors has also been complemented by growing scholarly interest in the various processes and social structures that underpin the emergence of these geographic and institutional differences - especially political, socio-economic, and cultural factors (Doherty et al., 2009; Hazenberg et al., 2016a; Hazenberg et al., 2016b; Mazzei, 2016; Salamon, 2003). Most recently, a focus on social structures and the network ties that link different stakeholders in the social enterprise sector has led to the creation of an ecosystem typology based on biological evolutionary theory, which argues that there is a need for greater pluralism in social enterprise ecosystems (Hazenberg et al., 2016b).

This chapter adds to this scholarship by examining the power structures that exist within social enterprise ecosystems, many of which inhibit or support the emergence of pluralism in relation to power and resources. Our decision to adopt a Weberian view of power allows us to explore how actors within ecosystems act "purposefully" and "rationally" to create value for themselves and others, while also emphasizing how these actions occur within social structures (i.e. networks) that facilitate the flow of resources to different segments of the ecosystem (i.e. social action) (Weber, 1978). By adopting this focus on power, we argue that social entrepreneurship, like social innovation, is a loaded term that is politically and socially constructed (Nicholls \& Murdock, 2012), and that dominant stakeholders use their power to develop narratives that compel actors within social enterprise ecosystems to behave in certain ways (Dey \& Steyaert, 2014). As Montgomery et al. (2016) argue in relation to social innovation, dominant discourse can limit or liberate the social and political capacities of citizens. Therefore, understanding how power structures shape discourse within social enterprise ecosystems and stakeholder networks is crucial in ensuring that sustainable social enterprise ecosystems can emerge. 


\section{Theoretical Framework}

\section{Evolutionary theory and social networks in social enterprise ecosystems}

A growing body of literature has emerged recently emphasizing the conceptualization of social enterprise sectors as ecosystems and the importance of "place" in the development of social economies (see, for example, Arthur et al., 2006; During, 2014; Grassl, 2012; Hazenberg et al., 2016a; Hazenberg et al., 2016b; Mazzei, 2016; Roy et al., 2015). The biological evolutionary approach often utilizes the concept of "autopoiesis", which argues that every organism (used as a metaphor here for stakeholders) within an ecosystem is a product of evolution within that system (Maturana \& Varela, 1987). Stakeholders are referred to here in the context of stakeholder theory, in which organizations are viewed as being responsible to a wider group of stakeholders-including suppliers, customers, partners, financiers, and wider society — upon which the organisation relies to exist (Freeman \& Reed, 1983; Freeman, 2010). Stakeholder theory also has resonance when discussing issues of power and social identity, as the power held by actors and institutions is central to how groups coalesce, mobilize, and act in response to hierarchy and political responsibility (Crane \& Ruebottom, 2011; Jensen \& Sandström, 2011).

Since social enterprise ecosystems are made up of several institutional actors, the identification of stakeholders as key organisms within the ecosystem is pertinent to the evolution of the ecosystem itself. Furthermore, this evolution is a two-way process in which environmental factors and the organism's "internal logics" shape its development (i.e. they behave individually depending upon their interpretation of environmental stimuli) (Van Assche et al., 2014). These internal logics are shaped by three main factors:

- genetic - the historical antecedents passed down through the generations to shape current organisational types within the ecosystem (for instance, shared/similar economic, political, and legal systems);

- phenotypes - variations that emerge within species due to environmental factors (such as the diversity of existing social enterprise organizational forms);

- epigenetics - when the nature of the organism's genetic coding is shaped by environmental factors and/or experiences (the role of political and socio-economic factors and policy) (During, 2014; During et al., 2016; Hazenberg et al., 2016b).

These three factors can lead to both divergent and convergent evolution in an ecosystem, a phenomenon that was identified by Hazenberg et al. (2016a) when exploring the evolution of the Scottish and English social enterprise ecosystems (see Figure 8.1 below).

\section{[INSERT FIGURE 8.1 HERE]}

While the use of biological evolutionary theory provides a useful metaphor for understanding the emergence and development of social enterprise ecosystems, it does not account for the social interactions that are crucial to any understanding of human socio-economic systems (although it can be argued that the "social" experience of stakeholders is an epigenetic factor). Communication in human ecosystems often shapes how people interpret and react to their environment (Luhmann, 1989). Therefore, the socially-embedded nature of economic systems (Granovetter, 1985) also needs to be accounted for when seeking to understand the development of social enterprise ecosystems, a new sub-species of enterprises that is based upon economic and social environmental factors (During et al., 2016). Indeed, the importance of "embeddedness" and stakeholder network analysis in social enterprise and social innovation research has already been identified as requiring further study (Shaw \& Bruin, 2013).

Granovetter's (1985) work on "embeddedness" is crucial in understanding how social networks, the relations between stakeholders, and hence power can mediate behavior within an ecosystem and create dominant narratives. Social network theory posits that the position of stakeholders (individual actors and organizations) within ecosystems both enables and inhibits the pursuit of their goals (Brass, 1984; Mehra, Kilduff, \& Brass, 2001; Qureshi, Bistruck, \& Bhatt, 2016), 
as it influences the flow of resources (economic as well as other forms of capital) between them (Jack, 2005; Uzzi, 1996). The growth of businesses and social enterprise does not occur in a vacuum, but is of course subject to socio-economic and political factors (Zafeiropoulou \& Koufopoulos, 2013). The extent to which these socio-economic and political factors affect social networks-and hence relations between stakeholders in ecosystems - often determines the type of ecosystem that emerges, the phenotypes that exist within them, and the power structures that actively shape the environment. Indeed, the role of power within an ecosystem is fundamental to its development. In the same way that a dominant species can shape its environment both positively and negatively - we need look no further than ourselves here - or that a dominant individual within a group can coerce/persuade others to their own goals, so can powerful individuals/organizations/groups have a significant impact on a social enterprise ecosystem.

\section{Power in social enterprise ecosystems}

Power and the ability to shape networks and resource flows are a fundamental element of this process, as stakeholders with power can shape narratives and defend or challenge dominant discourses (Weber, 1978). Furthermore, it could be argued that power is one of the most important factors in the evolution of social enterprise ecosystems, as it can act as a genetic factor, an epigenetic factor, and actively shape the emergence of phenotypes through the control of resource flows (i.e. policy and funding). ${ }^{1}$ If we accept that this is the case (see Dey \& Steyaert, 2014; Dey \& Teasdale, 2016; Nicholls, 2010), or at least that power is one of the more dominant factors in shaping discourse, then an exploration of pluralism in social enterprise ecosystems by analyzing concentrations of power is fundamental to understanding how sustainable and resilient ecosystems can be produced.

A Weberian view of the role of power in social networks argues that dominant stakeholders can control the flow of resources in order to shape social action to their own ends (Weber, 1978). Weber also examines the role of power and class, identifying that class distinctions are to a degree aligned with access to power and resources. Indeed, Weberian ideas of power and class are particularly pertinent to the current study due to the emergence of social enterprises in disadvantaged communities, many of whom traditionally lack access to power and resources, as many of these organizations (particularly at the smaller more localized end of the sector) lack the social networks and power required to leverage in resources. In ecosystems where relatively high levels of power and resources are concentrated among a small number of stakeholders, large sections of the ecosystem can be left exposed to the decisions made by a select group of actors, a process that Puumalainen et al. (2015) refer to as "high power distance." These actors can therefore wield disproportionate influence on the development of an ecosystem and drive paradigmatic shifts within it (Hazenberg et al., 2016b; Nicholls, 2010). This is a process that Montgomery (2016) identifies in relation to neoliberal manipulation of the concept of social innovation, and the way that neoliberal actors have used the language of social innovation (and social entrepreneurship) to shape discourse around public policy (see, for example, Have \& Rubalcaba, 2016).

This ability to compel and/or influence others to think and act in certain ways (Dey \& Steyaert, 2014) reinforces Weber's (1978) focus on the use of power and social structures to shape social action. While this can have positive ramifications for an ecosystem, it can also lead to reduced resistance to dominant discourses (Jones et al., 2015) and inhibit innovation, as stakeholders are less likely to challenge the social equilibrium (Dey and Steyaert, 2014; Zahra et al., 2009). Thus the role of power in controlling discourse, resource-flow, and potentially reducing pluralism in social enterprise ecosystems acts as the theoretical focus of this chapter and the research that underpins it. We argue that sustainable and resilient social enterprise ecosystems can only be achieved by creating low power distance (Puumalainen et al., 2015) and increasing pluralism.

\section{Methodology}


The findings reported in this chapter are the product of a mixed-methods research methodology, utilizing focus groups, semi-structured interviews, and stakeholder network mapping. We sought to identify the conditions under which social entrepreneurship and social innovation emerged across Europe, map the stakeholder networks that existed within social enterprise ecosystems, and understand the relative power dynamics at play in each ecosystem. The data-gathering process was cut into three phases. The first phase involved two city-level focus groups with local stakeholdersone that was targeted at social entrepreneurs and another that targeted other stakeholders (e.g. representatives from local government, policy-makers, and members of social enterprise support organizations) in each EFESEIIS participant country ${ }^{2}$. A total of 20 focus groups were held involving 141 participants.

The second stage involved semi-structured interviews of national stakeholders that were identified through the local focus groups (the interview questions were based upon the data that emerged in the focus groups). A total of 117 interviews were conducted, which meant that a total of 258 social enterprise stakeholders took part in our research. The data from the first two phases was then used to produce a stakeholder map for each country's ecosystem, which was then compared and contrasted with other countries in the study by the research leads (the EFESEIIS English team) in order to explore differences and commonalities. This analysis led to the creation of the social enterprise ecosystem typology discussed later in this chapter.

Our data analysis strategies featured a Straussian approach to grounded theory (Hekkala, 2007). The researchers have a general idea of where to begin, force the theory through structured questions, and rigorously code the data in order to reveal theory through structured analysis (Halewah, Fidler, \& McRobb, 2008). The Constant Comparative Method (CCM) was used to analyse the data (Glaser \& Strauss, 1967; Lincoln \& Guba, 1985). This approach has been successfully applied in previous studies of social venture creation and social enterprises (see Haugh, 2007; Hazenberg, 2014).

Seven main themes emerged from our research: procurement policies/regulation for social innovation; financial activities for ecosystem growth; inclusive labour market practices; collaborative stakeholder systems; training and education in support of ecosystem growth; impact and dissemination; and system drivers. All of these themes will be discussed in relation to two main areas of interest: the development of a stakeholder typology and pluralism in social enterprise ecosystems. Our data analysis methods and the development of the stakeholder typology discussed below were originally enunciated in Hazenberg et al. (2016b, 2016c).

\section{Developing a stakeholder typology}

Our data analysis led to the creation of a typology for social enterprise ecosystems that included four specific types: Statist-macro, Statist-micro, Private-macro, and Private-micro (see Figure 8.2 below for an overview of each typology). These types of ecosystems emerge based upon the dominant stakeholder types present in an ecosystem. For example, a Statist-macro ecosystem will feature a concentration of power among national and transnational public sector organizations. Conversely, a Private-micro ecosystem will have its discourse shaped by local, private sector stakeholders. This is not to say that other stakeholder types do not exist within an ecosystem; rather, we propose a generalized ecosystem typology that can be applied to different countries and/or regions depending upon the stakeholders that exist within them, the relational and structural links between these actors, and the power held by individual stakeholder groups. For each ecosystem type outlined below, the relevant countries engaged in the EFESEIIS project are listed next to the type that best aligns with their current situation. Our research also identified a "pluralistic zone," in which it is argued the ecosystem is balanced with low-power distance and diffused concentrations of power.

\section{Statist-macro ecosystems (Albania, Austria, France, Poland, and Serbia)}

Statist-macro ecosystems are typified by the predominance of state institutions in delivering support to social enterprise ecosystems (through funding, policy and legal/regulatory mechanisms) that 
emerge at the national and supra-national levels (European Union). Supra-national support is often received from international NGOs such as Ashoka, and there is a distinct lack of localism in relation to developing micro- and meso-level support for the social economy. Indeed, stakeholders in Poland bemoaned the lack of collaboration between local government and social enterprises, despite the obvious benefits to both stakeholder groups and a general alignment in values. This lack of localism and bottom-up social innovation does result in more homogenous support mechanisms across the ecosystem, but it also creates high power-distance between stakeholders (Puumalainen et al., 2015). As one participant noted:

"The money is inefficiently spent on social problems. While money is invested in the right projects, the way this is done is old-fashioned. The beneficiary group is seen as an object of support and not as subject/actors of change." (SE Practitioner, Austria)

In addition, the homogeneity of the support mechanism creates a lack of diversity in the "gene pool" of ecosystem actors (During et al., 2016) that can damage the sustainability and ability of the ecosystem to resist external exogenous shocks. This leads to the emergence of specific organizational forms - phenotypes - that are the result of public policy support and are therefore acutely vulnerable to changes in public policy (Hazenberg et al., 2016a). This lack of diversity leaves stakeholders subject to the whims of those wielding power within the ecosystem, and further encourages dominant stakeholders to use their power to shape social action in line with their own goals (Weber, 1978), ultimately reducing bottom-up social innovation (Have \& Rubalcaba, 2016). This demonstrates the ability of stakeholder (social) networks within ecosystems to enable and/or inhibit the actions of others and guide how they interpret their environment (Luhmann, 1989; Mehra, Kilduff, \& Brass, 2001; Qureshi, Bistruck, \& Bhatt, 2016). This allows certain stakeholders to be bypassed in Statistmacro ecosystems, as was recognized in Albania:

"Local government would be most appropriate to engage; of course it hasn't been engaged so far. A form would be providing public facilities with economic prices for social enterprises." (International NGO, Albania)

\section{Statist-micro ecosystems (Scotland and Sweden)}

Statist-micro ecosystems, while still utilizing public sector bodies to deliver support to social enterprise ecosystems, are typified by a greater focus on localism through local state institutions, even though supra-national financial support is often present (e.g. the European Social Fund and European Regional Development Fund). National policy and funding programs are limited, which leads to the emergence of heterogeneous local social enterprise ecosystems. This creates a more fragmentary landscape at the national level, as some local authorities/municipalities are more supportive of the social economy than others. This was identified by a Swedish stakeholder:

"A significant feature of the Swedish SE sector is that it is built around the work of local authorities, not national institutions. This has to do with the fact that many social entrepreneurs address local problems. Inevitably, the municipalities become their ally. The dependency is obviously mutual, but the fact remains that social enterprises always evolve on local basis. Thus, to enhance the development of the SE sector we need a better collaboration between the government and the municipalities." (Association of Local Authorities and Regions, Sweden)

The issue of power is central here, as it creates an ecosystem with both high and low power-distances (Puumalainen et al., 2015), depending on levels of support from local authorities. This type of ecosystem leads to a greater diversification of the gene pool of social enterprises (During et al., 2016), albeit one that is skewed towards "community businesses" (Hazenberg et al., 2016a, 2016b). Among 
local authorities in Statist-micro ecosystems - at least those local authorities that are supportive of the social economy-greater emphasis is placed on the empowerment of communities and creating low power-distance, while still acknowledging that convincing stakeholders to relinquish power is difficult. This is difficult because stakeholders are effectively being asked to surrender (or at least reduce) their ability to shape social actions (Weber, 1978), even if the surrender of power can lead to increases in bottom-up social innovation (Have \& Rubalcaba, 2016), greater independence (Dey \& Steyaert, 2014), and increased resistance to the emergence of dominant discourses (Jones et al., 2015), such as neo-liberal narratives on social innovation/entrepreneurship (Montgomery, 2016). Policymakers in Scotland recognized this when talking about their own experiences:

“We've got ALEOs in the Council - Arm's Length External Organizations - so the likes of Jobs \& Business Glasgow and Community Safety Glasgow, as well as Glasgow Life. They've all got a role to play in this. Part of this is about relinquishing power and that's a very difficult thing to persuade people to do. In fact, it's the hardest thing." (Local Authority, Scotland)

\section{Private-macro ecosystems (England and Germany)}

Private-macro ecosystems are epitomized by a dichotomy between limited state funding at the national level for social enterprise ecosystems, but significant levels of policy support and/or the creation of legal/regulatory frameworks. National governments tend to emphasize the marketization of the third sector in this type of ecosystem, an area that has received considerable focus in England (see, for instance, McKay et al., 2015). Marketization is a process in which the state develops policy mechanisms that are designed to encourage the growth of the social economy through the support of the private sector (i.e. social investors) and the public sector (competitive procurement processes). This often means that larger social enterprises are given preference over smaller, more localized organizations:

"I think they [local authorities] prioritize getting the bigger companies up and running and I think a conversation about policy and supporting smaller SEs might be helpful." (Social Entrepreneur, England)

While grant funding for the social economy comes mainly from national NGOS and supranational bodies such as the European Union, focus is often placed on homogenizing the third sector around the theme of marketization/sustainability. In Germany, for instance, research has shown that personal networks amongst stakeholders can inhibit or enable the winning of procurement contracts, again demonstrating the role of social interactions and stakeholder networks in shaping power (Luhmann, 1989; Mehra, Kilduff, \& Brass, 2001; Qureshi, Bistruck, \& Bhatt, 2016) and consolidating power (Weber, 1978).

"In a nutshell, in a relatively well functioning and structured country like Germany, we have an unbelievable dependency on persons [in procurement processes]" (Social Entrepreneur, Germany)

This ecosystem type embodies the role of centralized state power-albeit one that seeks to homogenize the ecosystem through market mechanisms - and, like its Statist-macro counterpart, is characterized by high power-distance (Puumalainen, 2015). The development of the social investment market in England provides a good example of this Weberian use of power by stakeholders (in this case policy-makers) to drive social action (see, for example, Hazenberg, 2017; Hazenberg \& Denny, In Press). While market forces can lead to some diversification in the "gene pool" of social enterprises (During et al., 2016), the homogenizing role of national policies and supranational funding mechanisms often undermines this process. Furthermore, these factors also reduce bottom-up innovation and prevent social enterprises from acting in an innovative manner (Dey \& 
Steyaert, 2014; Have \& Rubalcaba, 2016). This in turn leaves social enterprises powerless to challenge the status quo or pushes them towards challenging dominant narratives by engaging in "tactical mimicry" (Dey \& Teasdale, 2016; Zahra et al., 2009). Private-macro ecosystems represent what Montgomery (2016) refers to as the "technocratic paradigm of social innovation," which is an important feature of neoliberalism. Therefore, this ecosystem type demonstrates the ability of powerful actors across all sectors to drive social action and shape discourse based on their own dominant narratives (Weber, 1978).

"I think we suffer generally from a confused message from national government on these issues...Now government talks about localism and big society, there is nothing put on the table in terms of initial feasibility funding for people to take advantage of...It is about how things are addressed at local level..." (SE stakeholder, England)

\section{Private-micro ecosystems (Italy and the Netherlands)}

The Private-micro type, like its macro counterpart, is exemplified by a lack of state funding and a focus on marketization. However, this focus on market forces in shaping social enterprise ecosystems is not driven by centralized state policy, but rather by disparate third- and private-sector organizations operating at the local level. These organizations include associations, cooperatives, regional funding bodies, and NGOs. Depending upon the political approaches of local authorities and local procurement strategies, formal links are sometimes present between local social enterprises and government, oftentimes through service delivery contracts. This ecosystem type has emerged as a localized response to perceptions that the traditional welfare state is dysfunctional, and that the private sector is incapable of filling gaps in provision. This in turn leads to the creation of networks between third sector organizations and ecosystems that contain low power-distance (Puumalainen, 2015) and diffuse actors who use the social networks to shape action (Mehra, Kilduff, \& Brass, 2001; Qureshi, Bistruck, \& Bhatt, 2016).

"The welfare state model is definitely dead. The redistributive model and thus the public services cannot answer to the social needs. Hence, new enterprises emerge to cope with the rising demand. Nevertheless, the new contribution from the social sector cannot be reduced only as an answer to the shortage of public funding. I consider the value of social enterprise as a model that differs from the State intervention...The SEs' contribution rises from two premises: $i)$ there are unmet needs; ii) [there] exists a different answer in providing supply: the demand should be personalized rather than standardized." (SE Support Organisation, Italy)

Indeed, a large number of respondents from the Netherlands identified the importance of personal networks (informal and formal) in shaping social entrepreneurial success, over and above state bodies or public policy. This leads to a more diversified and heterogeneous ecosystem in which power is not centralized, although pockets of power invariably exist through stakeholders, such as regional associations and funders. As a result, bottom-up social innovation that challenges existing paradigms is more prevalent in these types of ecosystems (Dey \& Steyaert, 2014; Have \& Rubalcaba, 2016; Zahra et al., 2009;). The ability of smaller social enterprise actors/stakeholders to shape local ecosystem conditions is, from a Weberian perspective, easier to achieve, as power is more dispersed and individual horizons for social action are broader. This also leads to the emergence of more democratic organizations within the ecosystem, and an ecosystem that is more aligned to what Montgomery (2016) terms the "Democratic Paradigm of Social Innovation."

"Europe is far away from here in practice...... I do connect to the national government, but in a minimum way. My 'reality' is mostly here. When talking about an enabling environment, I experience other governmental organizations mostly abstractly, in a way that I do have to 
reckon with them, but I do not have a relationship with them...But I do have a lot of relations with people and companies here in the area. That is my enabling environment." (Academic, Netherlands)

\section{Overall social enterprise ecosystem typology}

The four ecosystem types outlined above form an overall typology of social enterprise ecosystems that is delineated by two axes: localism versus national/supranational forces, and the involvement of private, public, and third sectors in the ecosystem. These four ecosystem types have emerged as a result of each region's historical/cultural context (genetic); environmental factors in the socioeconomic and political spheres (epigenetic); and the social and stakeholder networks that exist within each ecosystem (During et al., 2016; Hazenberg et al., 2016a; 2016b; Luhmann, 1989). This emphasizes the importance of "place" in the emergence of social enterprise ecosystems (Mazzei, 2016), as well as social and stakeholder networks (Mehra, Kilduff, \& Brass, 2001; Qureshi, Bistruck, $\&$ Bhatt, 2016). However, it is important to stress that the identification of these four ecosystem types in each of the 11 countries is intended to provide a broad template for identifying social enterprise ecosystems, and that the use of biological evolutionary theory is largely metaphorical in nature (Hazenberg et al., 2016a, 2016b). Indeed, the boundaries between different ecosystem types are fluid, as ecosystems constantly shift in terms of their make-up and distinctive features. Nevertheless, this typology acts as a model for policy-makers and other stakeholders who support the social economy, allowing them to identify the types of support that might work best in a specific regional context. It also allows us to conceptualize a "pluralistic zone" for ecosystems that embody multiple characteristics, and where diverse stakeholder networks/relationships exist alongside low powerdistance and multiple narratives to enable flourishing, sustainable, and robust social enterprise ecosystems (Hazenberg et al., 2016b). This conceptual typology is illustrated below in Figure 8.2. The pluralism concept and its relation to Weberian power dynamics will be explored in greater depth in the next section.

\section{[INSERT FIGURE 8.2 HERE]}

\section{Pluralism in social enterprise ecosystems}

The typology presented above seeks to provide a template for understanding the types of social enterprise ecosystems that can emerge in geographic regions across Europe, and how their "embedded" nature shapes their emergence and ongoing development (Granovetter, 1985). Their "embeddedness" is characterized by the stakeholder and social networks that exist within the ecosystem, particularly the various actors that use these networks to access resources and interpret/shape their environment (Luhmann, 1989; Jack, 2005; Uzzi, 1996). This process also relates to stakeholder theory, as the manner in which ecosystem stakeholders respond to environmental factors and integrate into social networks is often shaped by power, hierarchy, and identity (Crane \& Ruebottom, 2011; Jensen \& Sandström, 2011). Indeed, stakeholders can use these networks - and their positions within them - to access or wield power, while also using this power to influence discourse in the environment, control resource flows, and enable/inhibit the social actions of others while pursuing their own goals (Weber, 1978). Using a Weberian view of power as a theoretical lens to understand social networks within the social economy enables academics (and other stakeholders) to better understand how to support the development of robust and sustainable social enterprise ecosystems. As noted earlier, ecosystems that are characterized by high power-distance (Puumalainen, 2015) - where high levels of power are concentrated in the hands of relatively few stakeholders - tend to produce lower levels of social innovation (Have \& Rubalcaba, 2016) and encourage the emergence of dominant narratives that distort reality and conceal truth (Dey \& Steyaert, 2014).

Greater network pluralism in social enterprise ecosystems should therefore be the goal of all social enterprise stakeholders who wish to see the development of robust and flourishing social 
economies around the world. Greater pluralism through diversified income streams, cultural relativism, informed policy, heterogeneous stakeholder groupings, and cross-sector trade (involving the private, public, and third sectors) makes social enterprise ecosystems more resistant to exogenous shocks and improves the ability of social enterprises to compete for survival (During et al., 2016; Hazenberg et al., 2016b). This is because pluralism increases the heterogeneity of organizational types (the genetic biodiversity of the ecosystem) and facilitates increased communication between stakeholders, thereby encouraging them to continually reassess their environment, challenge dominant narratives, enhance trust and collaboration, and increase innovation (Dey \& Steyaert, 2014; During et al., 2016; Have \& Rubalcaba, 2016; Jones et al., 2015; Luhmann, 1989; Qureshi et al., 2016; Zafeiropoulou \& Koufopoulos, 2013). This creates low power-distance within social enterprise ecosystems (Puumalainen, 2015) and limits the ability of certain actors to drive paradigmatic shifts (Hazenberg et al., 2016b; Nicholls, 2010;). Increasing network pluralism is therefore fundamental to the development of sustainable ecosystems and empowering socially-disadvantaged people.

\section{Summary and implications}

This chapter has sought to demonstrate how biological evolutionary theory, social network theory, and Weberian conceptions of power can inform our understanding of social enterprise ecosystems in relation to stakeholder networks and relationships, and how power can shape these networks and ecosystem development. Indeed, power within networks is crucial to the emergence of dominant narratives and discourses that shape how actors within the ecosystem perceive their environment and engage in social action. This in turn has powerful effects on the types of organizations that emerge, the policy frameworks that are developed, and the overall sustainability of the ecosystem itself.

We argue that the negative effects of power can best be countered through greater network pluralism within social enterprise ecosystems, which will reduce power-distance and increase social innovation. By developing a fluid typology of social enterprise ecosystems across Europe, our research encourages stakeholders to increase pluralism in their own ecosystems, and improve the sustainability of the social economy more generally. The findings outlined in this chapter (and more broadly in relation to stakeholder networks in the EFESEIIS project as a whole) also allow stakeholders to identify the most suitable support mechanisms in their locality. Further research that explores this typology outside of Europe would be beneficial, as would ongoing analysis of the 11 countries involved in this research, with special emphasis on their trajectories-their success in increasing pluralism.

\footnotetext{
${ }^{1}$ This chapter avoids developing a hierarchy of factors for the development of social enterprises, as this over-simplifies other factors at play, including individual agency and responsibility.

${ }^{2}$ EFESEIIS supports individuals, institutions, and governments seeking to develop the social economy by improving knowledge on social entrepreneurship. The 11 countries include: Albania, Austria, England, France, Germany, Italy, Netherlands, Poland, Scotland, Serbia, and Sweden. For more information about the project, see Chapter 2.
}

\section{References}

Brass, D. J. (1984). Being in the right place: A structural analysis of individual influence in an organization. Administrative Science Quarterly, 29, 518-539.

Crane, A., \& Ruebottom, T. (2011). Stakeholder Theory and Social Identity: Rethinking Stakeholder Identification. Journal of Business Ethics, 101(1), 77-87.

Defourny, J., \& Nyssens, M. (2008). Social enterprise in Europe: recent trends and developments. Social Enterprise Journal, 4(3), 202-228. 
Defourny, J., \& Nyssens, M. (2010). Conceptions of Social Enterprise and Social Entrepreneurship in Europe and the United States: Convergences and Divergences. Journal of Social Entrepreneurship, 1(1), 32-53.

Dey, P., \& Steyaert, C. (2014). Rethinking the space of ethics in social entrepreneurship: Power, subjectivity and practices of freedom. Journal of Business Ethics, 133, 627-641.

Dey, P., \& Teasdale, S. (2016). The tactical mimicry of social enterprise strategies: Acting 'as if' in the everyday life of third sector organisations. Organization, 23(4), 485-504.

Doherty, B., Foster, G., Mason, C., Meehan, J., Meehan, K., Rotheroe, N., \& Royce, M. (2009). Management for Social Enterprise. London: Sage Publications.

During, R. (2014). The Evolutionary Perspective on Social Enterprise. EFESEIIS FP7 Draft Paper, July 2014.

During, R., Van Dam, R., \& Salverda, I. (2016). Using evolutionary theory for pluralism in social policies. Paper presented at the Social Policy Association Conference - July $4^{\text {th }}-6^{\text {th }} 2016$, Belfast, Northern Ireland.

Freeman, R.E., \& Reed, D.L. (1983). Stockholders and stakeholders: A new perspective on corporate governance. California Management Review, 25(3), 88-106.

Freeman, R.E. (2010). Strategic management: A stakeholder approach. Cambridge: Cambridge University Press.

Galera, G., \& Borzaga, C. (2009). Social Enterprise: An International Overview of Its Conceptual Evolution and Legal Implementation. Social Enterprise Journal, 5(3), 210-228.

Glaser, B. G., \& Strauss, A. L. (1967). The Discovery of Grounded Theory. Chicago. IL: Aldine.

Granovetter, M. (1985). Economic action and social structure: The problem of embeddedness. American Journal of Sociology, 91, 481-510.

Grassl, W. (2012). Business Models of Social Enterprise: A Design Approach to Hybridity. ACRN Journal of Social Entrepreneurship Perspectives, 1(1), 37-60.

Halewah, M., Fidler, C., \& McRobb, S. (2008). Integrating the Grounded Theory Method and CaseStudy Research Methodology within IS research: A possible 'road map. Paper presented at the International Conference on Information Systems, ICIS Conference Proceedings Paper 165.

Haugh, H. (2007). Community-Led Social Venture Creation. Entrepreneurship, Theory \& Practice, 31(2), 161-182.

Have, R.P., \& Rubalcaba, L. (2016). Social innovation research: an emerging area of innovation studies. Research Policy, 45, 1923-1935.

Hazenberg, R. (2017). Investment readiness and sustainability: Social investment as a third sector policy panacea? Paper presented at the $21^{\text {st }}$ IRSPM Conference - April $19^{\text {th }}-21^{\text {st }} 2017$, Budapest, Hungary.

Hazenberg, R., \& Denny, S. (In Press). Critiquing the social investment market in England: Marketisation before sustainability. In P. Palmer \& M. Salway (Forthcoming), Social investment around the world. Gower Book Series.

Hazenberg, R., Bajwa-Patel, M., Roy, M.J., Mazzei, M., \& Baglioni, S. (2016a). A Comparative Overview of Social Enterprise 'Ecosystems' in Scotland and England: An Evolutionary Perspective. International Review of Sociology, 26(2), 205-222.

Hazenberg, R., Bajwa-Patel, M., Roy, M.J., Mazzei, M., \& Baglioni, S. (2016b). The role of institutional and stakeholder networks in shaping social enterprise ecosystems in Europe. Social Enterprise Journal, 12(3), 302-321.

Hazenberg, R., Bajwa-Patel, M., Qureshi, S., \& Field, M. (2016c). Stakeholder Networks Within Social Enterprise Ecosystems Across Europe. EFESEIIS Work Package 4 Report, August 2016.

Hekkala, R. (2007). Grounded Theory - the two faces of the methodology and their manifestation in IS research. Proceedings of the 30th Information Systems Research Seminar in Scandinavia IRIS, Scandinavia.

Jack, S. L. (2005). The role, use and activation of strong and weak network ties: A qualitative analysis. Journal of Management Studies, 42, 1233-1259. 
Jensen T., \& Sandström, J. (2011), Stakeholder Theory and Globalization: The Challenges of Power and Responsibility, Organization Studies, 32(4), pp. 473-488.

Jones, R., Betta, M., Latham, J., \& Gross, D. (2009). Female social entrepreneurship as a discursive struggle. AGSE, 871-85.

Kerlin, J.A. (2006). Social Enterprise in the United States and Europe: Understanding and Learning from the Differences. Voluntas, 17(3), 246-62.

Kerlin, J.A. (2010). A Comparative Analysis of the Global Emergence of Social Enterprise. Voluntas, $21,162-79$.

Kerlin, J. A. (2013). Defining Social Enterprise Across Different Contexts: A Conceptual Framework Based on Institutional Factors. Nonprofit and Voluntary Sector Quarterly, 42(1), 84-108.

Lincoln, Y., \& Guba, E. (1985). Naturalistic Inquiry. Beverly Hills, CA: Sage.

Luhmann, N. (1989). Ecological communication. Chicago: University of Chicago Press.

Maturana, H., \& Varela, F. (1987). The tree of knowledge: The biological roots of human understanding. Boston: Shambhala Publications.

Mazzei, M. (2017). Understanding difference: the importance of 'place' in the shaping of local social economies. Voluntas, 28(6), 2763-2784.

McKay, S., Moro, D., Teasdale, S., \& Clifford, D. (2015). The marketisation of charities in England and Wales. Voluntas, 26(1), 336-354.

Mehra, A., Kilduff, M., \& Brass, D. J. (2001). The social networks of high and low self-monitors: Implications for workplace performance. Administrative Science Quarterly, 46, 121-146.

Mendell, M. (2010). Reflections on the evolving landscape of social enterprise in North America. Policy and Society, 29(3), 243-256.

Montgomery, T. (2016). Are social innovation paradigms incommensurable? Voluntas, 27, 19792000.

Nicholls, A. (2010). The legitimacy of social entrepreneurship: Reflexive isomorphism in a preparadigmatic field. Entrepreneurship, Theory and Practice, 34(4), 611-633.

Nicholls, A., \& Murdock, A. (2012). The nature of social innovation. In A. Nicholls \& A. Murdock (Eds.), Social innovation: Blurring boundaries to reconfigure markets (pp. 1-30). Basingstoke and New York: Palgrave Macmillan.

Phillips, W., Lee, H., Ghobadian, A., O’Regan, N., \& James, P. (2015). Social innovation and social entrepreneurship: a systematic review. Group and Organisation Management, 40(3), 428-461.

Puumalainen, K., Sjögrén, H., Syrjä, P., \& Barraket, J. (2015). Comparing social entrepreneurship across nations: An explanatory study of institutional effects. Canadian Journal of Administrative Sciences, 32, 276-287.

Qureshi, I., Kistruck, G.M., \& Bhatt, B. (2016). The enabling and constraining effects of social ties in the process of institutional entrepreneurship. Organization Studies, 37(3), 425-447.

Roy, M.J., McHugh, N., Huckfield, L., Kay, A., \& Donaldson, C. (2015). The Most Supportive Environment in the World'? Tracing the Development of an Institutional 'Ecosystem' for Social Enterprise. Voluntas, 26(3), 777-800.

Salamon, L.M., Sokolowski, S.W., \& List, R. (2003). Global civil society: An overview. The John Hopkins Comparative Nonprofit Sector Project. Retrieved from http://ccss.jhu.edu/wpcontent/uploads/downloads/2011/09/Book_GCSOverview_2003.pdf

Shaw, E., \& Bruin, A. (2013). Reconsidering capitalism: the promise of social innovation and social entrepreneurship. International Small Business Journal, 31(7), 737-746.

Uzzi, B. (1996). The sources and consequences of embeddedness for the economic performance of organizations: The network effect. American Sociological Review, 61, 674-698.

Van Assche, K., Beunen, R., \& Duineveld, M. (2014). Evolutionary Governance Theory: An Introduction. Wageningen: Springer.

Weber, M. (1978). Economy and society: An outline of interpretative sociology. Berkeley, CA: California University Press. 
Zafeiropoulou, F.A., \& Koufopoulos, D.N. (2013). The Influence of Relational Embeddedness on the Formation and Performance of Social Franchising. Journal of Marketing Channels, 20(1-2), 73-98.

Zahra, S.A., Gedajlovicb, E., Neubaumc, D.O. \& Shulmand, J.M. (2009). A typology of social entrepreneurs: motives, search processes and ethical challenges. Journal of Business Venturing, 24(5), 519-532. 